\title{
Civics Is Largely About Politics: The Possibilities and Challenges of a Citizenship Education Pedagogy that Embraces Democratic Politics and Recognizes Diversity
}

\author{
L. Alison Molina-Girón \\ University of Regina \\ Canada
}

ABSTRACT: Research investigating the practice of citizenship education in multicultural schools is scarce. Drawing on classroom observations and teacher and student interviews in four multicultural Grade 10 Civics classrooms in Ottawa, Canada, this case study discusses one teacher's unique citizenship education pedagogy, an approach that embraces democratic politics and affirms diversity. Vignettes of class instruction illustrate the teaching strategies implemented and the struggles faced in employing this pedagogical approach. The case study contends that a critical multicultural citizenship education must have a strong political orientation and, additionally, be responsive to the existing social and cultural diversity that defines our democratic community.

KEYWORDS: citizenship education, multicultural citizenship, democracy, politics.

Democratic Politics Methodology

Educating Effective Citizens through Democratic Politics

Challenges to Teaching through Democratic Politics

Discussion

Notes

References

Author Contact

Increasingly, citizenship education occurs in racially, ethnically, culturally, and linguistically diverse classrooms. This rich diversity can be both a source of strength and a challenge. To a large extent, schools are microcosms of the larger society and, therefore, ideal settings where students from different backgrounds come together as citizens to learn about, discuss, and act on issues of public concern. But diversity also poses serious challenges: Most democratic, pluralistic societies face the daunting challenge of providing citizenship education capable of accommodating multiple forms of difference while still promoting the bonds, virtues, and practices needed to develop a socially cohesive democratic nation (Banks, 2004, 2007; Dilworth 2008; Gutmann, 2004; Kymlicka, 2004; Kymlicka \& Norman, 2000; Miller, 2000; Parker, 2003). Striving to strike that balance between unity, on the one hand, and diversity on the other, is a key challenge in democratic citizenship education (Banks 2004, 2007; Parker, 2003). 
Citizenship educators are increasingly recognizing that citizenship education must aim to prepare youngsters to live and function in increasingly multicultural, democratic societies. To succeed, citizenship education ought to be responsive to social and cultural diversity (Banks, 2007; Dilworth, 2008; Gutmann, 2004; Parker, 2003). What knowledge, skills, and values are crucial to effectively prepare citizens for democratic, pluralistic societies? How can teachers deliver citizenship education that takes into account students' social and cultural backgrounds while fostering a sense of interconnectedness and interdependence with the larger political community?

Despite a renewed interest in citizenship education in Canada and in many other countries, very little is known about the practice of citizenship education in diverse classrooms or the degree to which citizenship education is responsive to social and cultural difference. This case study is part of a larger study that sought to investigate the practice of citizenship education in four multicultural, grade 10, civics classrooms ${ }^{1}$ located in the City of Ottawa, Ontario, Canada (Molina-Girón, 2012, 2013). The initial study found that only one teacher sought to integrate social and cultural difference-as found in the student body and, moreover, society at large-as an integral aspect of his citizenship instruction. By contrast, the teachers in the other three civics classrooms studied reported that the existing social and cultural diversity has little to no effect on their citizenship instruction (Molina-Girón, 2012).

This in-situ qualitative study provides an example of a pedagogical approach to citizenship education that embraces democratic politics while, at the same time, affirming social and cultural diversity. I contend that these two notions are central to a critical multicultural citizenship education - one that aims to be responsive to the existing social and cultural diversity. This case study will shed light on the pedagogical decisions as well as the challenges involved in providing a critical multicultural citizenship education.

\section{Democratic Politics: A Framework for Multicultural Citizenship Education}

The provision of multicultural citizenship education begins with the recognition that a distinctive feature of the political community is the existence of multiple forms of social and cultural difference-along such lines as class, race, ethnicity, gender, cultural and religious orientation, and sexual preference-and that these lines can lead to a plurality of identities and different conceptions of the common good (Banks, 2004, 2007; Kymlicka, 2004; Parker, 2003). In addition, this recognition of diversity is directly connected to the values of civic and political equality, which can be understood as the structural inclusion of the various ethnic, cultural, and socially diverse groups in all aspects of the nation's civic, social, economic, and political life (Gutmann, 2004; Kymlicka, 2004; Kymlicka \& Norman, 2000; May, 1999). From this perspective, a critical 
multicultural citizenship education needs to be taught against the realm of democratic politics.

How should a society and its teachers educate citizens to effectively participate in the democratic process? While there is not a singular, unified theory or pedagogical approach to citizenship education, to some extent there is consensus as to the kinds of knowledge and skills citizenship teachers ought to inculcate in their students. At the very minimum, citizens ought to have some knowledge of how the basic democratic structure works (Delli Carpini, 2000; Milner, 2002; Parker, 2003). Citizenship education can provide students with a knowledge base of political institutions and processes (e.g., how bills become law, and citizen rights and responsibilities) and key political actors, political parties, and political organizations (e.g., political party leaders and party platforms) (Hess, 2009; Milner, 2002; Parker, 2003). Informed democratic participation also requires having knowledge of current, substantive government policy and critical problems. In addition, to participate effectively students must develop higher-order thinking skills (e.g., analyzing and assessing issues and forming and sustaining opinions), inquiry and communication skills (e.g., defining a problem and analyzing information from various sources), and politically related skills (e.g., debating and constructively challenging viewpoints) (Hess \& McAvoy, 2015; Milner, 2010; Parker, 2003).

However, for many-especially those concerned with citizen engagement in public life-citizenship education must move beyond developing civic-related knowledge and skills, as important as those are. Fundamentally, citizenship education must prepare youngsters to be active participants in their nation's civic and political life. Indeed, democracy not only requires its citizens' direct and continuous involvement in matters of public decision-making, but it becomes strengthened by it and benefits from it (Barber, 2003; Delli Carpini, 2000; Held, 1996, Hess \& McAvoy, 2015, Milner, 2010). As political philosopher David Held contends, an active citizenry participation "fosters a sense of political efficacy, nurtures a concern for collective problems, and contributes to the formation of an active and knowledgeable citizenry capable of taking a sustained interest in the governing process" (1996, p. 271).

Citizenship education programs that wish to prepare citizens for effective participation in multicultural societies like Canada's need to have a political orientation while also affirming social and cultural diversity as a distinctive trait of the political community. Programs with a political orientation conceive of competent citizens as those who possess "the knowledge and ability capacity of citizens to make sense of their political world" (Milner, 2002, p. 1). These programs make explicit the goals of educating youngsters for political understanding and competence (Almond \& Verba, 1989; Crick \& Lister, 1978; Parker, 2003). The view of politics adopted is neither one of seemingly straightforward democratic procedures nor simply what politicians and government officials do (Barber, 2003; Boyte, 2004; Parker, 2003). Rather, politics is the unavoidable "messy, inefficient, and conflict-ridden" work involved in dealing with the problems our society faces (Boyte, 2004; Crick \& Lister 1978; 
Milner, 2010, p. 11). Citizenship education with a clear political orientation aims to increase its students' political attentiveness by directing their attention to political and governmental affairs, discussing political and policy related issues, and encouraging participation in politically oriented activities such as rallies and petition signing (Almond \& Verba, 1989; Hess \& McAvoy, 2015; Crick \& Porter, 1978; Parker, 2003).

Democratic politics inevitably involve conflict, disagreements, differential power relations, and a struggle to achieve a vision of the common good. A citizenship education that embraces democratic politics helps students grapple with the demands of socially and culturally diverse groups for a more inclusive political system, one in which their voices and social practices, which have up to now occupied marginalized positions, can be included (Kymlicka, 2004; Kymlicka \& Norman, 2000; May, 1999; Miller, 2000). When a view of democratic politics is adopted, conflict is not seen as divisive or counter-productive but as valuable and integral to democracy itself (Miller, 2000; Szkudlarek, 2013).

A citizenship education that affirms diversity, in practice, moves beyond simply teaching students about the nation's internal diversity and promoting tolerance ${ }^{2}$ for practices and beliefs different from our own. Such teachings alone fall short of promoting civic and political equality (Gutmann, 2004; Kincheloe \& Steinberg, 1997). Citizenship education programs concerned with civic and political equality acknowledge historical injustices experienced by minorities and teach the complexities, dilemmas, and challenges of living in multicultural societies (Kincheloe \& Steinberg, 1997; Parker, 2003). More specifically, these programs make it a priority to help students grapple with current political conflicts; the diversity of views and interests at stake; the way that power operates; and ultimate beneficiaries in the decision-making process (Boyte, 2004; Crick \& Lister, 1978; Delli Carpini, 2000; Hess \& McAvoy, 2015; Parker, 2003).

\section{Methodology}

This article focuses on the results of a qualitative study of four Grade 10 Civics classrooms taught in three urban high schools, data drawn from a larger project (Molina-Girón, 2012, 2013). ${ }^{3}$ The study employed a combination of nonparticipant observations ${ }^{4}$ and individual and mini focus group interviews with teacher and students. Observations in each classroom ranged from 10 to 15 sessions of 75 minutes each, accounting for a total of 58 hours of observations. Formal (and informal) interviews were conducted with each of the four civics teacher and also with 30 students taking the course. Interviews with teachers lasted from 45 minutes to an hour. Individual and focus group student interviews lasted between 15 to 40 minutes. All interviews followed a semi-structured format and were tape-recorded and later transcribed verbatim. Citizenship-related documents were also analyzed including the prescribed Civics curriculum, Ontario Ministry of Education and Training [OMET] and school board guidelines, 
instructional materials (e.g., textbook and handouts) and examples of students' work. The schools selected for the study are among those that have the highest enrolment of immigrant students in the Ottawa region. In addition, all schools are located in residential neighborhoods near Ottawa's downtown core and belong to the same school board.

Data analysis was iterative and followed two phases: within-case and cross-case analyses (Stake, 2006). The within-case analysis began with the identification of categories, patterns, and themes to which data was assigned. For each classroom, a case report that presents a detailed picture of how citizenship education occurs was written. The cross-case analysis was approached as "the study of diversity" (Ragin, 2000), focusing on identifying commonalities and differences across cases and on whether and how teachers' citizenship instruction was responsive to the multicultural character of Canadian society. The cross-case analysis revealed that only one particular teacher-Mr. Anthony Bennett (pseudonym)-took into account social and cultural difference in his civics instruction. In the next section, I present examples of class instruction to illustrate how in Mr. Bennett's citizenship pedagogy social and cultural diversity is an integral aspect in educating for democratic citizenship.

The study was conducted in Willow High School (pseudonym) that serves a lower-income community of 44,050 inhabitants with an average household income of $\$ 64,697$ in $2011^{5}$ (City of Ottawa, 2014). The community is racially and ethnically diverse with $30 \%$ of the population having a native tongue other than English or French (City of Ottawa, 2014). In the community, $7.9 \%$ of the population is of Arabic origin (the second largest Arabic-speaking population in the city), $6.4 \%$ of African origin, and $4.2 \%$ are recent immigrants (City of Ottawa, 2014; Centre for Research and Education in Community Services [CRECS], 2015).

Data was collected through observations and interviews in Mr. Bennett's Civics class. Mr. Bennett is a White teacher in his mid-40s who has taught the Grade 10 Civics course for the past eight years. Reflective of the neighborhood, Mr. Bennett's class is racially and ethnically diverse: He estimates that $20 \%$ of the students are new immigrants and about $60 \%$ are first- or second-generation immigrants from the Middle East (i.e., Lebanon, Iraq, Somalia, and Pakistan) or Africa (Eritrea and Ethiopia). I observed Mr. Bennett teaching a two-week unit on democratic decision-making covering the following themes: political parties, elections and political participation.

\section{Educating Effective Citizens through Democratic Politics: Mr. Anthony Bennett's Civic Class}

There are two pivotal notions underlying Mr. Bennett's conceptions of good citizenship education. The first is his belief that "civics is largely about politics." The second stems from his support for multiculturalism. "I strongly 
believe in multiculturalism," so "promot[ing] multiculturalism and the belief that it is possible to get along" is a key goal of Mr. Bennett's instruction. He espouses a Deweyian view of democracy as a work in progress and an ideal for living together. Democracy, Mr. Bennett asserted, "is something that is not easy... that is very difficult" and to which "there is no easy solution." Consequently, teaching about cultural pluralism - the peaceful coexistence among people from distinct groups-"[is also] a complicated thing to teach with...so many and different people. I feel I have to try and hope to have a positive effect."

A central aspect of his citizenship education pedagogy is recognition of the students' varying backgrounds: Developing an appreciation for the students' backgrounds, he affirmed, "is my key to how I teach." Mr. Bennett tends to employ an issue-based approach that helps to frame civic content while providing a forum in which to explore the realities, tensions and conflicts involved in a democracy concerned with justice and equity: "I believe it is uninspiring to teach something nobody connects to." To achieve his vision of a citizenship education centered on democratic politics and pluralism, Mr. Bennett's classroom instruction seeks to instill political competence by engaging students with democracy as an ideal and not just as a form of government, building their knowledge base regarding politics and issues of public policy, exploring citizenship as a reflective practice, and practicing democratic decision-making.

Student engagement with democratic politics began with a trip to Parliament Hill to observe a session of the House of Commons, the popularly elected component of Canada's Parliament or law-making body. Mr. Bennett wanted his students to be familiar with key political figures (e.g., Canada's Prime Minister) and to witness how Members of Parliament [MPs] "propose, debate and pass laws." Mr. Bennett's students quickly learned from their observations of MPs in session in the Canadian House of Commons that political discourse often involves "multiple, sometimes competing, priorities and differing conceptions of the common good." As Mr. Bennett perceptively observed, his students are constantly being exposed to a wide and conflicting range of political information: They "hear these names: Bush, Clinton, Harper, or Obama, and they formulate opinions... on very small amounts of information." Therefore, a central goal of his instruction is for students to develop "a clear understanding of the political ideologies that are involved, so they have a broader...grid in which to place politicians...and events like the war, and terrorism.... I hope...they understand...that there are opposing views."

\section{Democracy: A Field of Forces}

"Life exists in a state of tension.... The same is in society.... There is a lot of pushing and pulling in different directions." These were Mr. Bennett's opening remarks the first day of Civics class. Mr. Bennett introduced his students to the structures and processes of Canada's democratic system but also went beyond by describing democracy as a field of forces with multiple players, often 
contrasting democratic principles and conceptions of the common good. Conflict, the common good and the eight elements of democracy (the rule of law, political equality, the common good, personal freedoms, human dignity, political freedoms, being informed and getting involved, and respect) are what he describes "the backbone of the course."

Mr. Bennett has described conflict as an inevitable part of democratic living, something that cannot always be resolved through consensus and constitutional law (Crick \& Porter, 1978). He categorically stated, "There is so little opportunity for people to deal with conflict in a peaceful way that we lose the skill to negotiate. In my class, conflict is welcomed and embraced." Dealing with conflict necessarily involves teaching about "the common good... the ability to think of others." Thus, dialogue across differences is central "to deal[ing] with conflict to find solutions people can live with."

In Mr. Bennett's classroom the democratic values of justice, fairness, and equity were meaningfully brought to the forefront. Importantly, issues of discrimination, racism, and classism were not eschewed, but rather discussed openly, and viewed as a lived societal reality. Mr. Bennett vividly illustrated how democratic societies sometimes fall far short of their ideals with a classroom discussion about barriers to economic opportunity. Mr. Bennett told the students that in a democracy, "people govern themselves in a manner that will serve their aspirations." People, he explained, aspire to three things: economic opportunity, political freedom, and social justice. To the question, "What is economic opportunity?" one student, Mahirah, answered, "finding the right job." Another, Sebastian, added, "a job for everyone." "Is this the case in Canada?" Mr. Bennett asked them pointedly. "There is racism," acknowledged one student, Mahal. "Some employers will not hire you if your skin is of a certain colour," added Patrick. Mr. Bennett encouraged the dialogue by asking, "What is justice?" "Fair treatment" and "Equality!" were two students' responses. Mr. Bennett then explained that in Canada the Constitution and the Charter of Rights and Freedoms guarantee civic rights (e.g., freedom of speech), political rights (e.g., right to vote) and social rights (e.g., access to education). In practice, however, not all citizens and groups in Canadian society enjoy the same rights. "Today," Mr. Bennett concluded, "discrimination and racism prevent justice and equality of economic opportunities for all."

\section{Encouraging Student Engagement with Politics and Issues of Public Policy}

Mr. Bennett's citizenship instruction encouraged students to think politically. The way in which he taught the political parties unit of the Civics class is a good example. Often, political parties are taught as if they were static, preformed structures to which politicians belong and for which citizens vote. However, Mr. Bennett taught that political parties are dynamic entities whose members work to gain public support to get elected. A political party, he stated, 
"is a group of people who want power...who want to run the country...and put their ideas into effect."

Mr. Bennett showed his students the 1998 film Bulworth to illustrate this point and spark discussion. In brief, Bulworth tells the story of broken-down American Senator Jay Bulworth who appears doomed to lose his re-election bid and decides to commit suicide. Insurance companies are lobbying Congressmen to stop legislation that would make mandatory offering insurance to all, including low-income and high-risk citizens. If passed, the insurance industry stands to lose millions of dollars. Senator Bulworth agrees to vote to support the insurance industry in exchange for a $\$ 10$ million life insurance policy that he plans to leave to his daughter. The following is an example of how he used the film to teach about political campaigns, a mandated curriculum topic. In a pivotal scene, Senator Bulworth, while attending a political rally at an African American church, tells the crowd that senators do not care about disadvantaged people except for their votes. His distraught campaign manager asks Bulworth, "What is the campaign strategy?!"

Mr. Bennett explained the film's political backdrop and key concepts and, by referring to characters and scenes in the film, used the film to teach his students about a mandated curriculum topic. Mr. Bennett posed the following questions to his students: "Is it common for a candidate to say that they don't care about poor people? What is the difference between the message the campaign manager prepared and what Bulworth told the crowd? Why is his campaign manager concerned?" He then introduced the concept of political image and asked his students, "What is a political image?" One student, Connor, replied, "[it is] the physical strength, money, appearance, intelligence." Another, Salma added, "[political image is] what gets people to vote for you." One's political image, Mr. Bennett affirmed "is the heart of a politician's campaign... it is what an MP tries to promote, what he stands for." Mr. Bennett then went on to explain that politicians have agendas and need public support to act on them once elected. Political agendas can be hidden or disguised by appealing images and messages. Thus, as citizens, he affirmed, "we need to go past [beyond] the image and think what it is that a politician really stands for."

\section{Citizenship Is a Reflective Process}

Based on a vision of citizenship as a reflective practice (Newmann, 1975), Mr. Bennett's citizenship pedagogy included learning experiences that asked students to ponder their own political views and position themselves politically with regards to conflicting issues and policies. He gave the students a handout entitled, The Political Spectrum: Where Do You Stand?, presenting 12 statements on public policy issues related to post-secondary education, immigration, and state-sponsored programs for disadvantaged groups. Mr. Bennett asked his students to reflect on their personal stance and explain why they were or were not in agreement with statements like "Immigrants should be 
sent to parts of the country that have...a labour shortage," "The death penalty should be automatic in all cases of premeditated murder," and "Rising tuition fees make post-secondary education inaccessible to too many students....The government [should] fund all levels of education." After having his students complete the handout, Mr. Bennett introduced them to the three main political parties-Conservative, New Democratic Party (NDP), and Liberal-and explained where each party falls within the political spectrum: right, left, and center. The students were asked to review each policy statement and identify which political party they thought most likely to support each. For example, the statement on access to post-secondary education would have been most closely identified with the words "left-wing, NDP policy," in other words, to the left of centre on the political spectrum. Using a visual of the political spectrum, Mr. Bennett then asked his students to compare their own positions with those of the political parties on the 12 policy statements. His students commented that their political views tended to spread across the political spectrum. "You see," Mr. Bennett concluded, "nobody is completely right- or left-wing.... There is tension." "What is more important," he stressed, "[is to] listen to the issue and decide your position toward that issue." Gita raised her hand and asked, "Are right-wing good or bad people?" Mr. Bennett was momentarily taken aback by her question but then explained that "the political spectrum is not about being good or bad.... It is about understanding that parties and citizens can have different beliefs and values about an issue and can propose different actions in trying to solve it."

\section{Practicing Democratic Decision-making}

For Mr. Bennett, practicing decision-making is a must to learning in his Civics course. In a sweatshop role-playing exercise, the students explored labor relations and worker exploitation. Divided into four groups, the students came together to negotiate a $10 \%$ salary cut to workers at a shoe factory located in Honduras, a developing country. Each student represented a different stakeholder: the shoe company CEO, the factory owner, the assembly line workers, the First World consumers, and a labour rights NGO. According to the company's CEO, salary cuts were necessary in order to stay profitable against heavy competition. Each student representative received a handout outlining the positions they would have to take in the negotiation.

Before the simulation took place Mr. Bennett discussed what a sweatshop is. Most students knew famous companies that use sweatshops to produce their products, including Nike, ${ }^{\circledR}$ Adidas ${ }^{\circledR}$ and Guess. ${ }^{\circledR}$ Students defined a sweatshop as "a place where you get paid funny." Mr. Bennett further explained that sweatshops rely on cheap labor from people in poor countries-a strategy that allows companies to ensure and expand their profit potential. "In sweatshops," he told the students, "people work 12-hour shifts for a minimum salary and have no benefits." Students conceded that they buy these brands "because we are bombarded with advertisements." As a form of reflection, Mr. Bennett informed 
his students that the professional golf player Tiger Woods "makes more money from Nike than all the people working for Nike in Indonesia." Mr. Bennett then explored with them the avenues workers have to negotiate salary disputes, such as forming unions and going on strike. By going on strike, "the company [can stand to] lose millions of dollars," he informed the students.

Of four discussion groups, three could not come to an agreement, resulting in a decision by the workers to strike. In the group that came to an agreement, the workers accepted a 3\% salary cut, with the promise that the salary cut would be reversed once the company's profits improved. In the discussion following the activity, a student reflected on the discrepancy between workers' salary and the company's profits: Cemal said, "These companies make millions of dollars every year.... Workers work eight hours a day for four dollars and they are still complaining." Jamila recognized how difficult it is for those in first-world countries-herself included-to boycott or give up buying these brands: "I know what they do," she said, "but I will still buy their brands." To close the activity Mr. Bennett remarked, "I hope you have a better understanding of what the situation is all about [and how we as] blind consumers are implicated in the exploitation of people around the world."

\section{What Students Report Learning?}

All students interviewed reported learning about the legal-political structure and institutions of democracy. Hashir, for example, reported learning about "the rule of law, the common good...The Charter of Rights and Freedoms, the different levels of government and how a bill is passed. Also, your [individual] rights." Student interviews revealed, furthermore, that students attached other meanings to democracy, such as democracy being a work in progress requiring citizens' input and involvement. Daniel highlighted learning the value of listening across differences: "I always had my point of view but now I understand and I can listen to other people's point of views and try to compromise." For others, democracy is associated with a vision of a more just society: "Democracy," asserted Nasira, "means, to me, fairness, equality, and multiculturalism." When asked why she associates these words with democracy, she explained: "I learned...how in downtown there are these homeless people and that not everyone is the same.... I am middle class, so my life is actually pretty good [compared] to poor people, but I never thought much about it [before taking Mr. Bennett's Civics class]."

\section{Challenges to Teaching through Democratic Politics}

Mr. Bennett's citizenship pedagogy, for the most part, encouraged students to critically engage with issues and policies that demand citizen and government attention. His pedagogical approach to citizenship education asked 
students to consider issues of power, equity, and justice in relation to issues of race, social class, gender, and sexual orientation. However, at times Mr. Bennett's instruction did not align with his own politically-oriented conceptions of citizenship. In the following section, I address two challenges to a more authentic pedagogical approach to citizenship education: (a) uncritical approaches to multiculturalism; and (b) promoting authentic classroom discussion.

Mr. Bennett endorsed the powerful narrative that Canada is a nation of immigrants (James, 2011). He told the students that Canada's Confederation was made possible by people from different cultures-Scottish, Irish, English, and French-coming together across colonies and territories: "The basic belief was that they could get along even though they were from different cultures and places." As Mr. Bennett explained to his students, Canada, from its inception, embraced the principle of multiculturalism. A student named Jacob raised his hand and said, "You are saying that they didn't want to conquer each other... but isn't it what happened?" Mr. Bennett took a moment to reflect before conceding, "At the beginning, yes [they weren't looking to conquer but conquest did, ultimately, take place]." He continued: "In Canada over the years people from different cultures have lived together.... Multiculturalism [and peaceful coexistence] is something we can do when other countries [seemingly] can't."

While it is beyond the scope of this paper to provide a critical examination of Canada's history of assimilation, suffice to say that racial and ethnic minorities remained disenfranchised citizens until the passing of the Canadian Bill of Rights in 1960. When history is taught without a critical edge, students gain little insight into the historical roots of inequalities in wealth, social status, and access to opportunities and resources among citizens and across groups (James, 2011; Kincheloe \& Steinberg, 1997).

Hess (2009) draws a distinction between classroom talk and classroom discussion. Classroom talk refers to teacher-student exchanges on a given topic, while classroom discussion is a well-planned process where students frame and research a problem, listen to different points of view, weigh alternatives, and apply problem-solving and decision-making skills (Hess, 2009; Parker, 2003). Mr. Bennett's conception of good citizenship education is rooted in a view of deliberative democracy (Held, 1996; Miller, 2000). He made explicit the importance of dialogue in teaching about conflict and controversial issues. Indeed, his classroom approach involved his posing critical questions on issues of public concern. However, most of the exchanges that took place in Mr. Bennett's Civics classes qualify as classroom talk-with limited student participation. Student exposure to conflict and controversial issues is beneficial, but it sometimes falls short of helping students understand what it truly means to come together as citizens to discuss and deliberate on issues for which there are multiple and competing views (Hess, 2009; Parker, 2003). 


\section{Discussion}

Why is Mr. Bennett's citizenship instruction responsive to the existing social and cultural diversity found in the classroom and, moreover, in society at large? I argue that a critical multicultural citizenship instruction-one that is responsive to social and cultural diversity —needs to do two things: (a) take a political orientation; and (b) affirm social and cultural diversity as a distinctive characteristic of the political community. These two notions underlie Mr. Bennett's citizenship pedagogy. For him, "Civics is largely about politics." Additionally, as he has asserted, he strongly believes in multiculturalism. Therefore, an important goal of his instruction is to "teach people how to get along." While this statement can be seen as aiming to improve human relations across cultural and racial lines (Kincheloe \& Steinberg, 1997), in practice Mr. Bennett's instruction does direct students' attention towards structural inequities, many faced by minorities.

Mr. Bennett's citizenship pedagogy has a decided political orientation. As such, his instruction goes beyond teaching the structures and processes of democracy to develop in his students both an understanding of politics and political competence. His approach does not minimize the importance of civic knowledge. As he affirmed, "To get kids [to be] more aware of their power they need to learn the structure." Mr. Bennett's students do learn about the structure and processes of our democratic system from within the context of politics and issues of public policy. His citizenship pedagogy presents a more dynamic and complex version of democracy, a version illuminated through difficult and often controversial issues of public governance: e.g., immigration legislation and government-funded welfare programs. Through a variety of teaching strategies Mr. Bennett creates spaces that allow students to experience an involvement as citizens in matters of public concern (Delli Carpini, 2000; Held, 1996; Newmann, 1975; Parker, 2003). In addition, his citizenship pedagogy takes seriously the notion that citizenship is a reflective practice for enlightened public participation (Newmann, 1975; Parker, 2003). In this context, real-life issues serve as a framework upon which students can ponder and better understand, on one hand, the centrality of power, conflict, and contrasting visions of the common good and, on the other, the congruence and contradictions of democratic ideals such as equality, freedom, and justice.

Teaching with a political orientation is not a lesson plan on local or global inequities but a stance and, therefore, a practice that is filled with ambiguities and contradictions. For many teachers, sustaining a kind of citizenship education that embraces politics and acknowledges social and cultural diversity can be a challenge. I have discussed two shortcomings in Mr. Bennett's citizenship instruction related to his ideological stance and pedagogical practice. With regards to ideological stance, this empirical research shows that even when teachers endorse more critical understandings of good citizenship education-as is the case of Mr. Bennett-their instruction can, in actuality, end up endorsing 
the values of the dominant ideology. In addition, teachers' pedagogical approaches may not support intended instructional goals, for example, Mr. Bennett's emphasis on the importance of learning about conflict and dialogue. Arguably, not all issues can be taught through classroom discussion and deliberation. However, Mr. Bennett's citizenship provided limited opportunities for students to investigate in-depth relevant societal issues that were presented to them.

A citizenship education that embraces democratic politics and affirms social and cultural diversity is rooted in particular conceptions of democracy and citizenship. Living democratically is beyond formal structures: it is primarily a way of life concerned, fundamentally, with equity, justice, critical thought, and decision-making. In addition, being a citizen is more than having legal status with state rights and responsibilities. The citizen is, above all, a "political actor" (Barber, 2003) involved in matters of public affairs. A critical multicultural citizenship education that embraces democratic politics while also affirming diversity lays a foundation toward building a more equitable society. Through such an approach, students learn important concepts such as how power influences public decision making; the unequal distribution of resources and its effect on different individuals and groups; why longstanding issues of inequity like racism are permitted to persist. This foundation is essential to develop in our youngsters the civic agency and commitment needed to tackle the mounting challenges our democracy faces.

\section{Notes}

1. In Canada, education is a provincial responsibility. In 2000, the OMET introduced Civics (CHV20), a required, half-credit (55 hours), non-streamed course for Grade 10 students. Civics (Politics) is the only high school course with a focus on public affairs and governance. In this course students will explore "rights and responsibilities associated with being an active citizen in a democratic society" (OMET, 2013, p. 147). The course is organized around three strands: political inquiry and skill development, civic awareness and civic engagement, and action (OMET, 2013).

2. Creppell (2003) explains that tolerance conceived as respect for others ignores power differentials and, in so doing, fails to disrupt the status quo. In addition, for those in the majority group, being tolerant is a display of good will which, in turn, validates the norms and ways of being of the dominant culture.

3. The names of all people and schools are pseudonyms.

4. This research uses non-participant observation of class instruction. As a researcher, I observed civic classes without becoming an active participant in participants' behaviors, interactions, and roles in teaching about citizenship.

5. In 2011 , In Canada, the average household income after-tax was $\$ 79,600$ (Statistics Canada, 2013a). In 2010, the average income in the province of 
Ontario was $\$ 71,523$ (Statistics Canada, 2013b) and in the city of Ottawa was $\$ 79,356$ (Statistics Canada, 2013c).

\section{References}

Almond, G., \& Verba, S. (1989). The civic culture: Political attitudes and democracy in five nations. Newbury Park, CA: Sage.

Banks, J. A. (2004). Introduction: Democratic citizenship education in multicultural societies. In J. A. Banks (Ed.), Diversity and citizenship education: Global perspectives (pp. 3-15). San Francisco, CA: JosseyBass.

Banks, J. A. (2007). Educating citizens in a multicultural society ( $2^{\text {nd }}$ ed.). New York, NY: Teachers College Press.

Barber, B. (2003). Strong democracy: Participatory politics for a new age ( $2^{\text {nd }}$ ed.). Berkeley, CA: University of California Press.

Boyte, H. C. (2004). Everyday politics: Reconnecting citizens and public life. Philadelphia, PA: University of Pennsylvania Press.

Centre for Research and Education in Community Services (CRECS). (2015). Ottawa neighborhood study (2015). Retrieved from http://neighbourhoodstudy.ca/

City of Ottawa (2014). City of Ottawa open data catalog. Retrieved from http://data.ottawa.ca/en.

Creppell, I. (2003). Toleration and identity: Foundations in early modern thought. New York, NY: Routledge.

Crick, B., \& Lister, I. (1978). Political literacy. In B. Crick \& A. Porter (Eds.), Political education and political literacy (pp. 37-46). London, UK: Longman.

Crick, B., \& Porter, A. (Eds.) (1978). Political education and political literacy. London, UK: Longman.

Delli Carpini, M. (2000). In search of the informed citizen: What Americans know about politics and why it matters. The Communication Review, 4(1), 129164.

Dilworth, P. P. (2008). Multicultural citizenship education. In J. Arthur, I. Davies, \& C. Hahn (Eds.), The SAGE handbook of education for citizenship and democracy (pp. 424-437). Los Angeles, CA: SAGE.

Gutmann, A. (2004). Unity and diversity in democratic multicultural education: Creative and destructive tensions. In J. A. Banks (Ed.), Diversity and citizenship education: Global perspectives (pp. 71-96). San Francisco, CA: Jossey-Bass. 
Held, D. (1996). Models of democracy. Stanford, CA: Stanford University Press.

Hess, D. E. (2009). Controversy in the classroom: The democratic power of discussion. New York, NY: Routledge.

Hess, D. E., \& McAvoy, P. (2015). The political classroom: Evidence and ethics in democratic education. New York, NY: Routledge.

James, C. E. (2011). Multicultural education in a color-blind society. In C. A. Grant \& A. Portera (Eds.), Intercultural and multicultural education: Enhancing global interconnectedness (pp. 191-210). New York, NY: Routledge.

Kincheloe, J. L., \& Steinberg, S. R. (1997). Changing multiculturalism. Philadelphia, PA: Open University Press.

Kymlicka, W. (2004). Foreword. In J. A. Banks (Ed.), Diversity and citizenship education: Global perspectives (pp. xiii-xviii). San Francisco, CA: JosseyBass.

Kymlicka, W., \& Norman, W. (2000). Citizenship in culturally diverse societies: Issues, contexts, concepts. In W. Kymlicka \& W. Norman (Eds.), Citizenship in diverse societies (pp. 1-41). New York, NY: Oxford University Press.

May, S. (1999). Critical multiculturalism and cultural difference: Avoiding essentialism. In S. May (Ed.), Critical multiculturalism: Rethinking multicultural and antiracist education (pp. 11-41). London, UK: Falmer Press.

Miller, D. (2000). Citizenship and national identity. Cambridge, UK: Polity Press.

Milner, H. (2002). Civic literacy: How informed citizens make democracy work. Hanover, NH: University Press of New England.

Milner, H. (2010). The internet generation: Engaged citizens or political dropouts. Hanover, NH: University Press of New England.

Molina-Girón, L. A. (2012). Educating good citizens: A case study of citizenship education in four multicultural high school classrooms in Ontario. Unpublished doctoral dissertation. University of Ottawa, Ontario, Canada.

Molina-Girón, L. A. (2013). Educating active citizens: What roles are students expected to play in public life? In L. E. Bass (Series Ed.) \& S. K. Nenga \& J. K. Taft (Vol. Ed.), Sociological studies of children and youth: Vol 16. Youth engagement: The civic-political lives of children and youth (pp. 4772). Bingley, UK: Emerald.

Newmann, F.M. (1975). Education for citizenship action: Challenge for secondary curriculum. Berkeley, CA: MrCutchan Publishing Corporation.

Ontario Ministry of Education and Training (OMET). (2013). The Ontario curriculum grades 9 and 10: Canadian and world studies (Revised). Retrieved from https://www.edu.gov.on.ca/eng/curriculum/.../ canworld910curr2013.pdf 
Parker, W. (2003). Teaching democracy: Unity and diversity in public life. New York, NY: Teachers College.

Ragin, C. C. (2000). Fuzzy-set social science. Chicago, IL: University of Chicago Press.

Stake, R. (2006). Multiple case study analysis. New York, NY: The Guilford Press.

Statistics Canada (2013a). Average income after tax by economic family types (2007 to 2011). Retrieved from http://www.statcan.gc.ca/tablestableaux/sum-som/l01/cst01/famil21a-eng.htm

Statistics Canada (2013b). NHS profile, Ontario, 2011. Retrieved from http://www12.statcan.gc.ca/nhs-enm/2011/dp$\mathrm{pd} /$ prof/details/page.cfm?Lang=E\&Geo1=PR\&Code1=35\&Data=Count\& SearchText=Ontario\&SearchType=Begins\&SearchPR=01\&A1=All\&B1=A II\&TABID=1

Statistics Canada (2013c). NHS profile, Ottawa, CV, Ontario, 2011. Retrieved from https://www12.statcan.gc.ca/nhs-enm/2011/dp-pd/prof/details/ page.cfm?Lang=E\&Ge01=CSD\&Code1 $=3506008 \& D a t a=C o u n t \& S e a r c h$ Text=Ottawa\&SearchType=Begins\&SearchPR=01\&A1=All\&B1=All\&Cust $\mathrm{om}=\& T A B \mid \mathrm{D}=1$

Szkudlarek, T. (2013). Introduction: Education and the political. In T. Szuklarek (Ed.), Education and the political: New theoretical articulations (pp. 1-13). Rotterdam, The Netherlands: Sense Publishers.

\section{Author Contact}

Alison Molina-Giron: alison.molina-giron@uregina.ca

University of Regina: 3737 Wascana PKWY, Regina, SK, S4S 0A2, Canada. 